\title{
Regression of the Fibrous Disease of the Breast in a Non-Diabetic Woman after Pregnancy and Breastfeeding
}

\begin{abstract}
Fibrous mastopathy, also known as diabetic mastopathy and lymphocytic mastopathy, may mimic breast cancer at the physical examination, mammography, and ultrasound. We report a case of a woman who presented a non-tender mass clinically suggestive of breast carcinoma; however, the fine-needle aspiration cytology indicated atypia and the core needle biopsy revealed lymphocytic mastopathy. The magnetic resonance imaging of the breast showed a lesion with benign features. It was not demonstrated diabetics mellitus and autoimmune diseases. The patient got pregnant, breastfed, and it was observed the progressive regression of the lesion, with complete disappearance of the solid mass. Three years and three months later, there was no palpable mass at the clinical examination and ultrasound. In conclusion, fibrous mastopathy shall be considered for all breast lesions, regardless of the diagnosis of diabetes mellitus. Once a definitive diagnosis of this pathology is reached, it is recommended clinical, imaging studies and fine-needle aspiration biopsy follow-up of the patient, avoiding unnecessary surgical procedures. (Arq Bras Endocrinol Metab 2007;51/9:1539-1543)
\end{abstract}

Keywords: Mastopathy; Fibrous mastopathy; Diabetic mastopathy; Lymphocytic mastopathy; Diabetes mellitus

\section{RESUMO}

Regressão de Mastopatia Fibrótica após Gravidez e Amamentação em uma Mulher Não Diabética.

A mastopatia fibrótica, também conhecida como mastopatia diabética e mastopatia linfocítica, pode, ao exame clínico, mamografia e ultra-som, simular um carcinoma mamário. Descrevemos o relato de uma mulher na qual o nódulo foi inicialmente suspeito de carcinoma mamário, mas o diagnóstico pela punção aspirativa com agulha fina foi de atipia, e o com biópsia com agulha grossa foi de mastopatia linfocítica. A ressonância magnética da mama mostrou a lesão com características de benignidade. Não foram demonstradas diabetes mellitus e doenças auto-imunes. A paciente engravidou, amamentou e foi observada regressão progressiva da lesão, com desaparecimento da mesma. A paciente persiste sem lesão na mama ao exame clínico e de ultra-som após acompanhamento de três anos e três meses. Em conclusão, a mastopatia fibrótica deve ser considerada para todas as lesões de mama, mesmo em pacientes sem diabetes mellitus. Quando o diagnóstico definitivo da patologia for realizado, é recomendável o acompanhamento da paciente com estudos clínicos e de imagem e biópsia com agulha fina, evitando-se procedimentos cirúrgicos desnecessários. (Arq Bras Endocrinol Metab 2007;51/9:1539-1543)

Descritores: Mastopatia; Mastopatia fibrótica; Mastopatia diabética; Mastopatia linfocítica; Diabetes mellitus apresentação de caso

\author{
Maria Aparecida Q. F. Pereira \\ Marcos E. DE A. SEGURA \\ ana Maria de Souza Santos \\ LuIz Augusto Casulari
}

Service of Mastology, Hospital de Base do Distrito Federal, Brasilia - DF, Brazil.

Recebido em 18/04/07

Aceito em 20/07/07 
$\mathrm{T}$ HE FIBROUS MASTOPATHY, also known as diabetic mastopathy and lymphocytic mastopathy, is an uncommon fibroinflammatory lesion described initially by Soler and Khardori, in 1984 (1), in a series of 12 patients with long-standing insulin-dependent diabetes mellitus.

Clinically it may appear as a rock-hard, irregularly outlined, uni or bilateral, solitary or multiple, synchronous or non-synchronous breast mass (2). At the clinical examination, mammography, and ultrasound, the lesion can mimic breast cancer (3). Magnetic resonance imaging may, in many cases, reveal the benign feature of the lesion $(4,5)$. Cellular material from fineneedle aspiration biopsy (FNAB) shows usually scarce cellularity, making the cytological diagnosis difficult (2). Ultrasound guided core needle biopsy, in the majority of the cases, is helpful in making the diagnosis but, in some situations, it is necessary to undergo surgical biopsy $(6,7)$.

In this paper, we report a case of a woman who presented a hard mass located at the union of the upper quadrants of the right breast. Clinical evaluation, mammography, and ultrasound suggested breast carcinoma. However, histopathological evaluation revealed a lymphocytic mastopathy lesion.

\section{CASE REPORT}

Woman, 30 years old, physician, in 12/19/2003 presented with a nodule in the right breast of 1 -month duration, growing rapidly.

Menarche had occurred at age 11 and her menstrual periods had always been regular. For the past 30 months, she used oral hormone contraceptive. She was

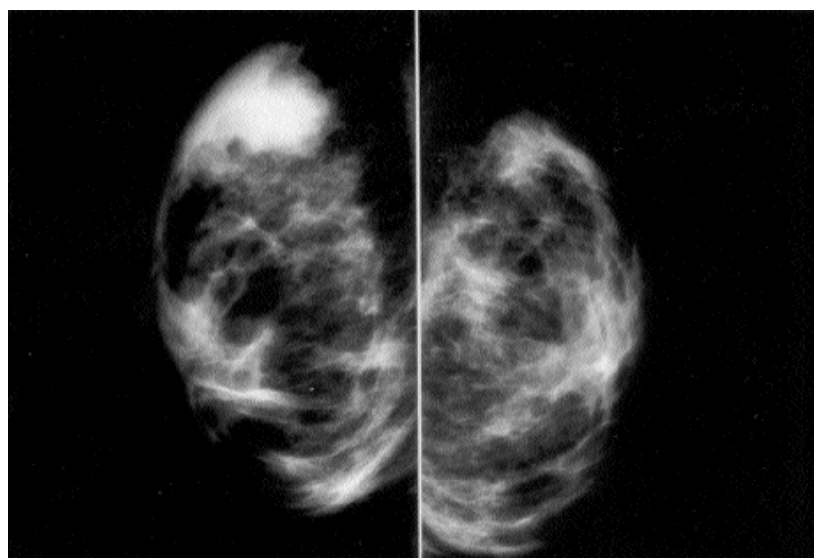

Figure 1. Mammography of the right breast shown asymmetrical density, classified as BI-RADS IV. nulliparous. She denied other pathologies such as alcoholism and tobaccoism. She referred stress and denied depression. Two relatives had breast cancer: her aunt from father's side at the age 45 and her grandmother from mother's side, post-menopause. Her mother had hypothyroidism and her father and grandfather from father's side had type 2 diabetes mellitus.

On physical examination, as of $12 / 19 / 03$, she appeared in good health. Breasts did not show bulging and/or retractions. On palpation of her right breast, there was a $2 \times 2 \mathrm{~cm}$ non-moveable hard mass with imprecise borders, in the union of the upper quadrants of her right breast. No axillary lymphadenopathy was noted. There was no abnormality in the left breast.

On $11 / 20 / 03$, as presented in figure 1 , mammography showed asymmetrical density, classified as BI-RADS IV (8). Breast sonography showed a solid mass in the right breast, with irregular contours and imprecise limits, measuring $3.2 \times 2.2 \times 1.4 \mathrm{~cm}$ associated to posterior acoustic shadowing with indeterminate features, in the 11-o'clock position (figure 2).

Prior to presentation at the Unit of Mastology, she underwent FNAB and core biopsy on 12/08/03, both procedures guided by ultrasound. It was observed a $2 \times 2 \mathrm{~cm}$ solid mass, located in the 12 o'clock position of the right breast, distant $2 \mathrm{~cm}$ from the nipple. Cytopathological examination revealed scattered cellularity, presence of intact epithelial ductal cells, adipocytes, spindle shaped stromal cells, and myoepithelial cells. In addition, due to presence of focal ductal cells with loss of cytoplasm cohesiveness, anisokaryosis and discrete hyperchromatic nuclei, "epithelial proliferation with atypical changes" diagnosis was done. The core biopsy showed mammary tissue with stromal fibrosis, discrete lymphocytic infiltration,

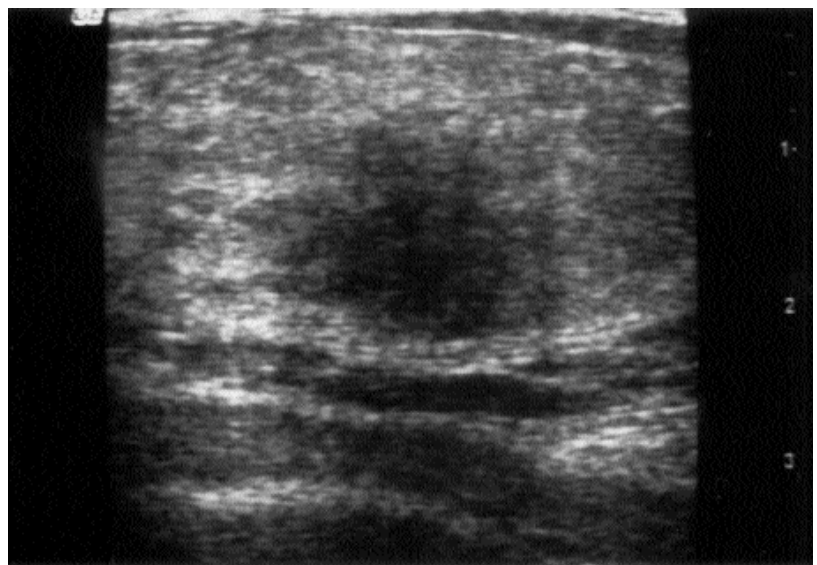

Figure 2. Breast ultrasonography of the right breast shown a solid mass with irregular contours and imprecise limits, measuring $3.2 \times 2.2 \times 1.4 \mathrm{~cm}$. 


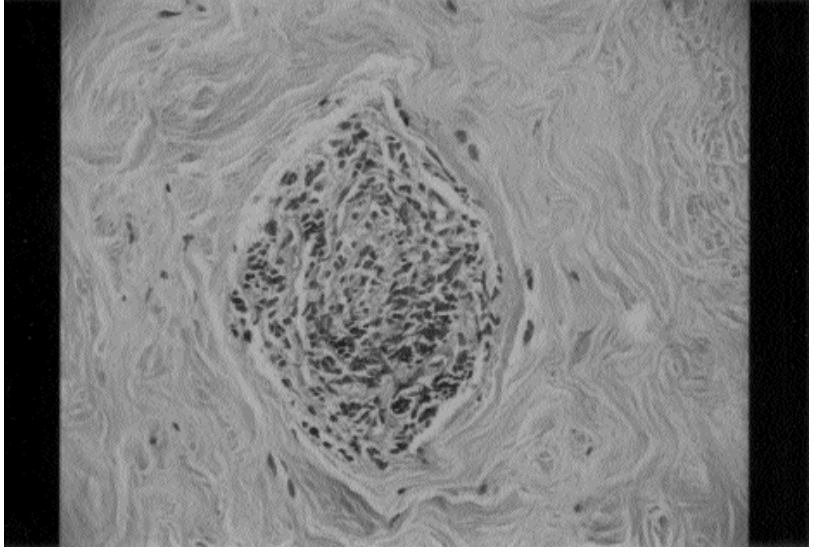

Figure 3. Growth mammillary lobulus due to light infiltrate inflammatory by lymphocyte characterizing lymphocytic lobulitis (HE - 200X)

sometimes invading the epithelium, compatible with lymphocytic mastopathy. The re-evaluation of the cytopathological material concluded that the atypias previously reported as epithelial atypias were, in fact, epithelioid fibroblasts. Therefore, the FNAB analyzed corresponded to stromal tissue (fibrous), compatible with fibrous mastopathy (figure 3). Histopathological re-evaluation was conclusive for fibrous mastopathy with lymphocytic lobulitis.

The magnetic resonance imaging of the breasts was performed on $12 / 19 / 03$. The images showed a $2.0 \times 1.3 \mathrm{~cm}$ solid mass in the right breast, with no precise limits and low-contrast enhancement (figure 4 ). The analysis of time intensity curve showed gradual and progressive enhancement without washout in the delayed phase, indicating a benign lesion. The magnetic resonance imaging of the left breast was normal (figures not shown).

The assessment to other associated causes was negative: hemogram, free T4 $(1.19 \mathrm{ng} / \mathrm{dL})$, total T3 (171.2 ng/dL), TSH $(3.42 \mu \mathrm{UI} / \mathrm{mL})$, thyroid antibodies (antithyreoglobulin and antiperoxidase), antinuclear antibodies, and LE cells were not present, rheumatoid factor $(8 \mathrm{IU} / \mathrm{mL})$, VHS $(10 \mathrm{~mm} / \mathrm{lh})$, ultra sensitive C-reactive protein $(0.17 \mathrm{mg} / \mathrm{dL})$, and $\mathrm{CH} 100$-total serum complement activity (100 $\mu \mathrm{CEO})$. The classic oral glucose tolerance test showed normal results: glucose fasting $84 \mathrm{mg} / \mathrm{dL}$ (normal values 70 to $100 \mathrm{mg} / \mathrm{dL}$ ) and 120 minutes $104 \mathrm{mg} / \mathrm{dL}$ $(\leq 140 \mathrm{mg} / \mathrm{dL})$.

It was agreed upon to monitor the patient with clinical examination and ultrasound of the lesion. On $08 / 23 / 04$, the patient presented by clinical examination a nodular area measuring $3 \times 2 \mathrm{~cm}$ in the right breast, and presented by the ultrasound a little hypoe-

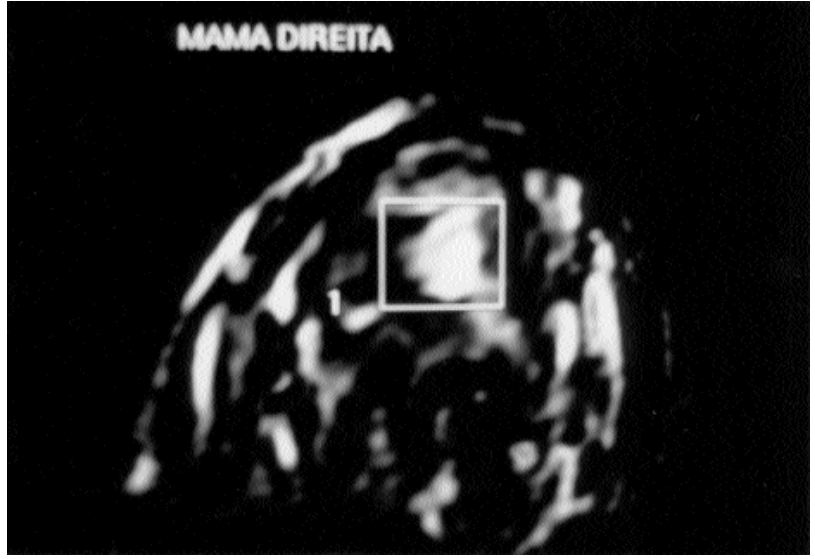

Figure 4. Magnetic resonance imaging of the right breast shown a $2.0 \times 1.3 \mathrm{~cm}$ solid mass with no precise limits and low-contrast enhancement.

choic area measuring $3 \times 1.6 \times 2.5 \mathrm{~cm}$. In 2005 , the patient got pregnant with no intercurrences during the pre-natal. At the $5^{\text {th }}$ gestational month, simplified oral glucose tolerance test showed normal results: glucose baseline $77 \mathrm{mg} / \mathrm{dL}$ and 60 minutes $118 \mathrm{mg} / \mathrm{dL}$ ( $130 \mathrm{mg} / \mathrm{dl}$ ), which was sustained at the $8^{\text {th }}$ gestational month: glucose fasting $70 \mathrm{mg} / \mathrm{dL}$ and insulin fasting $2.7 \mu \mathrm{UI} / \mathrm{mL}$ and postprandial $8.1 \mu \mathrm{UI} / \mathrm{mL}$. At the $5^{\text {th }}$ gestational month, hemogram, TSH, T4, and T3 levels were normal. By the ultrasound as of $05 / 04 / 05$, it was shown a little more hypoechoic area corresponding to the densest palpable area, with no clear nodule characterization. At the $8^{\text {th }}$ gestational month, the clinical and ultrasound examinations revealed normal breasts conditions in pregnancy period. In $11 / 2005$, she gave birth to a single fetus, male, weighting 3,725 $\mathrm{g}$ and APGAR 7 and 10, at the first and fifth minutes, respectively. She breastfed exclusively for sixth months and she interrupted breastfeeding at the end of the seventh month. At the final phase of breastfeeding, there were non-palpable solid mass or ultrasound imaging of the lesion previously identified. The patient continues with no sign of the lesion on both clinical and ultrasound examinations, after a 3 -year and 3-month follow-up.

\section{DISCUSSION}

Fibrous mastopathy occurs more frequently in patients with long-standing diabetes mellitus type 2 , but it may occur in patients with diabetes mellitus type 1. The pathogenesis of diabetic mastopathy remains unknown, but it is probably a multifactorial disease $(9,10)$. According to Byer et al. (11), the pathogenesis of dia- 
betic mastopathy could be summarized by the following sequence of events: 1st) extracellular matrix expansion and accumulation secondary to prolonged hyperglycemia during the diabetes process, 2 nd) production of alternated non-enzymatic glycosylated end products with neoantigen formation, production of alternated non-enzymatic glycosylated end products with neoantigen formation, 3rd) B cell predominant inflammation with hypothetical autoimmune response directed against neoantigens, and 4th) cytokine release secondary to the autoimmune process with consecutive, further matrix accumulation. Furthermore, some authors suggest that exogenous insulin use may play a role in the development of diabetic mastopathy (12-15).

Other factors may also be involved in the pathogenesis of diabetic mastopathy, since there are cases of non-diabetic patients or patients who have never used exogenous insulin (16-18), as it is the case reported. The patient did not develop gestational diabetes and her only relation to diabetes mellitus was the fact that her father and grandfather from father's side had type 2 diabetes mellitus. It is possible to hypothesize that the genetic load associated to diabetes mellitus may play a role in the aetiology of fibrous mastopathy. Further studies are required to investigate this potential role of genetic load.

The investigation of autoimmune diseases in the present patient indicated the inexistence of other diseases that might be associated to the diabetic mastopathy, such as systemic lupus erythematosus and hypothyroidism (16-18). The incidence of diabetic mastopathy among healthy individuals, as is the case of the patient, has been described by other authors ( 9 , 19-21).

In the current report, the patient had a breast lesion suggestive of cancer by the clinical examination, mammography, and the ultrasound. Regarding the cytopathological studies, the first one revealed epithelial atypia, reinforcing suspicion of cancer. However, re-evaluation of that material indicated that the cytopathological changes were due to epithelioid fibroblasts, characteristic of fibrous mastopathy. Cytopathological features of fibrous mastopathy are unspecific, so that the cytopathologist shall report the fineneedle aspiration as compatible with fibrous tissue. To make diagnostic conclusions it is necessary to correlate cytopathologic findings with other clinical data $(10,22)$. Some lesions with prominent epithelioid fibroblasts may mimic infiltrating breast carcinoma, especially lobular carcinoma. The similarity between pleomorphic lobular carcinoma cells and the epithelioid fibroblasts make the diagnosis quite difficult. In both cases, cytopathologic material is scarce and reveals occasional loose cellular clusters. Some morphological features and immunocytochemical examination can aid to distinguish between pleomorphic lobular carcinoma cells and epithelioid fibroblasts. Because of its epithelial origin, lobular carcinoma cells are positive for the cytokeratin and epithelial membrane antigen, while epithelioid fibroblasts are negative for these markers and positive for histiocyte differentiation antigens as CD68 (23).

Some lesions are non-palpable and detectable only on the mammography (24). They can still be identified as a heterogeneously dense breast tissue or an asymmetrical density in the breast, as observed in the patient. On the mammography, they may or not be visible. In the eight cases described by Byrd et al. (25), it was difficult to make the diagnosis and breast cancer was the differential diagnosis, as it happened to the patient.

The magnetic resonance imaging of the breast may be useful for confirming the benign features of the pathology. Dynamic contrast-enhanced magnetic resonance imaging of the patient revealed a homogeneous low-enhancement with a gradual and progressive course without a washout, which is characteristic of benign lesions of low vascularity. By being a potential criterion for making a differentiation between diabetic mastopathy and malignant processes, magnetic resonance imaging spares patients from excisional biopsy (20). The same pattern of contrast enhancement was observed for this patient. However, in some cases, it is difficult to differentiate diabetic mastopathy from breast cancer using magnetic resonance images. In these cases, FNAB or surgical excisional biopsy shall be undertaken $(6)$.

The patient had progressive regression and disappearance of the lesion concomitantly to pregnancy and breastfeeding, without recurrence of the lesion over a 3-year and 3-moth period of follow-up. There are just a few cases, in the literature, reporting the disappearance of a diabetic mastopathy lesion, as in the case reported. For example, Bayer et al. (11) discussed the case of a 45 year-old woman with diabetes mellitus since she was 19, who had progression and regression of the disease during the 5 -year follow-up period. Still, the surgical excision of the lesion was not indicated to the patient given that, approximately, $1 / 3$ of the lesions tends to recur after excision (9), generally in the same location of the excision, five years after initial appearance (26). The follow-up of the lesion shall be done even though there is no evidence of increased risk of neoplasia or lymphoma in breast tissue affected 
by fibrous mastopathy $(10,27,28)$. However, Mackey et al. (3) described the presence of breast carcinoma arising within the mastopathy in a woman submitted to a renal transplant.

In conclusion, fibrous mastopathy shall be considered for all breast lesions, regardless of the diagnosis of diabetes mellitus. Once a definitive diagnosis of this pathology is reached, it is recommended clinical, imaging studies, and FNAB follow-up of the patient, avoiding unnecessary surgical procedures.

\section{REFERENCES}

1. Soler NG, Khardori R. Fibrous disease of the breast, thyroiditis, and cheiroarthropathy in type I diabetes mellitus. Lancet 1984; $1: 193-5$.

2. Logan WW, Hoffman NY. Diabetic fibrous breast disease. Radiology 1989;172:667-70.

3. Mackey SP, Sinha S, Pusey J, Chia Y, McPherson GA. Breast carcinoma in diabetic mastopathy. Breast 2005;14:392-8.

4. Wong KT, Tse GM, Yang WT. Ultrasound and MR imaging of diabetic mastopathy. Clin Radiol 2002;57:730-5.

5. Yajima S, Fukutomi T, Akashi-Tanaka S, Nanasawa T, Miyakawa K, Hasegawa T. Diabetic mastopathy: a case report with reference to the findings of enhanced computed tomography. Breast Cancer 2001;8:246-9.

6. Sakuhara Y, Shinozaki T, Hozumi Y, Ogura S, Omoto K, Furuse M. MR imaging of diabetic mastopathy. Am J Roentgenol 2002;179:1201-3.

7. Andrews-Tang D, Diamond AB, Rogers L, Butler D. Diabetic mastopathy: adjunctive use of ultrasound and utility of core biopsy in diagnosis. Breast J 2000;6:183-8.

8. American College of Radiology. Breast Imaging Reporting and Data System (BI-RADS). 3rd ed. Reston: American College of Radiology, 1998.

9. Allen PW, Fisher C. Selected case from the Arkadi M. Rywlin International Pathology Slide Seminar: diabetic mastopathy. Adv Anat Pathol 2001;8:298-301.

10. Camuto PM, Zetrenne E, Ponn T. Diabetic mastopathy: report of 5 cases and a review of literature. Arch Surg 2000;135:1190-3.

11. Bayer U, Horn LC, Schulz HG. Bilateral, tumorlike diabetic mastopathy-progression and regression of the disease during 5-year follow up. Eur J Radiol 1998;26:248-53.

12. Tomaszewski JE, Brooks JS, Hicks D, Livolsi VA. Diabetic mastopathy: a distinctive clinicopathologic entity. Hum Pathol 1992;23:780-6.
13. Morgan MC, Weaver MG, Crowe JP, Abdul-Karim FW. Diabetic mastopathy: a clinicopathologic study in palpable and nonpalpable breast lesions. Mod Pathol 2005;8:349-54.

14. Garstin WI, Kaufman Z, Michell MJ, Baum M. Fibrous mastopathy in insulin dependent diabetics. Clin Radiol 1991;44:89-91.

15. Davies JD. Sclerosing lymphocytic lobulitis and autoimmune mastitites. Histopathology 1992;21:397.

16. Williams PH, Rubin CME, Theaker JM. Sclerosing lymphocytic lobulitis of the breast. Clin Radiol 1995;50:165-7.

17. Ashton MA, Lefkowitz M, Tavassoli FA. Epithelioid stromal cells in lymphocytic mastitis - a source of confusion with invasive carcinoma. Mod Pathol 1994;7:49-54.

18. Lammie GA, Bobrow LG, Staunton MD, Levison DA, Page G, Millis RR. Sclerosing lymphocytic lobulitis of the breast-evidence for an autoimmune pathogenesis. Histopathology 1991; 19:13-20.

19. Balan P, Turnbull LW. Dynamic contrast enhanced magnetic resonance imaging and magnetic resonance spectroscopy in diabetic mastopathy. Breast 2005;14:68-70.

20. Tuncbilek N, Karakas HM, Okten O. Diabetic fibrous mastopathy: dynamic contrast - enhanced magnetic resonance imaging findings. Breast J 2004;10:359-62.

21. Zimmerli L, Yurtsever $H$, Conen $D$, Truninger K. A diabetic breast lump. Lancet 2000;357:1670.

22. Peppolini L, Buttaro FM, Cristallini EG. Diabetic mastopathy. A report of two cases diagnosed by aspiration cytology. Acta Cytol 1997;41(4 suppl):1349-52.

23. Cooper Z, McKay MP. Diabetic mastopathy. Am J Emerg Med 2004;22:498.

24. Shaffrey JK, Askin FB, Gatewood OM, Brem R. Diabetic fibrous mastopathy: case reports and radiologic-pathologic correlation. Breast J 2000;6:414-7.

25. Byrd BF, Hartmann WH, Graham LS, Hogle HH. Mastopathy in insulin-dependent diabetics. Ann Surg 1987;205:529-32.

26. Ely KA, Tse G, Simpson JF, Clarfeld R, Page DL. Diabetic mastopathy. A clinicopathologic review. Am J Clin Pathol 2000;113:541-5.

27. Kudva YC, Reynolds C, O'Brien T, Crotty TB. Mastopathy and diabetes. Curr Diab Rep 2003;3:56-9.

28. Kudva YC, Reynolds C, O'Brien T, Powell C, Oberg AL, Crotty TB. "Diabetic mastopathy" or sclerosing lymphocytic lobulitis is strongly associated with type 1 diabetes. Diabetes Care 2002;25:121-6.

Address for correspondence:

Maria Aparecida de Queiroz Freitas Pereira

SGAS 910 - Conjunto B - Bloco E - Salas 120/122

70390-100 Brasília, DF

Fax: (61) 3443-7978

E-mail:magfp@uol.com.br 